\title{
Combined selection for grain yield, cooking quality and minerals in the common bean ${ }^{1}$
}

\author{
Seleção combinada para produtividade de grãos, qualidade de cozimento e minerais \\ em feijão comum
}

\author{
Nerinéia Dalfollo Ribeiro ${ }^{2 *}$, Ritieli Baptista Mambrin ${ }^{3}$, Lindolfo Storck ${ }^{4}$, Marina Prigol ${ }^{5}$ e Cristina Wayne \\ Nogueira $^{6}$
}

\begin{abstract}
Combined selection for grain yield, cooking and nutritional quality is important in the improvement of the common bean (Phaseolus vulgaris L). The objectives of this study therefore were to evaluate the genetic variability of the common bean lines as to grain yield, cooking time and the minerals concentration in the grains, to study the linear association between these characteristics and use the $\bar{Z}$ index to select those advanced lines which are superior in most of these characteristics. To do this, 16 common bean lines were evaluated in two growing seasons. The data were subjected to variance analysis and the Pearson correlation, and the $\bar{Z}$ index was then estimated. The lines presented genetic variability for grain yield, cooking time and calcium and iron concentrations in the grains. Low values for the correlation estimates were found between grain yield and concentrations of potassium $(\mathrm{r}=-0.3497)$, zinc $(\mathrm{r}=0.3486)$ and copper $(\mathrm{r}=0.2729)$. The Gen $\mathrm{Pr}$ 14-2-3 line presents the highest $\bar{Z}$ index for grain yield, cooking time and concentrations of potassium, iron, zinc and copper in the grains, being recommended for controlled hybridization in common bean breeding programs for biofortification.
\end{abstract}

Key words: Phaseolus vulgaris L. Genetic variability. Pearson correlation. $\bar{Z}$ Index.

\begin{abstract}
RESUMO - A seleção combinada para produtividade de grãos, qualidade de cozimento e nutricional é importante para o melhoramento de feijão comum (Phaseolus vulgaris L). Portanto, foram objetivos deste trabalho avaliar a variabilidade genética das linhagens de feijão comum quanto à produtividade de grãos, o tempo de cozimento e a concentração de minerais nos grãos, estudar a associação linear entre esses caracteres e utilizar o índice $\bar{Z}$ para selecionar as linhagens avançadas com superioridade para a maioria dos caracteres. Para tanto, foram avaliadas 16 linhagens de feijão comum em duas épocas de cultivo. Os dados obtidos foram submetidos à análise de variância e de correlação de Pearson e o índice $\bar{Z}$ foi estimado. As linhagens apresentaram variabilidade genética para a produtividade de grãos, o tempo de cozimento e a concentração de cálcio e de ferro nos grãos. Estimativas de correlação de baixa magnitude foram obtidas entre a produtividade de grãos e as concentrações de potássio $(\mathrm{r}=-0,3497)$, de zinco $(\mathrm{r}=0,3486)$ e de cobre $(\mathrm{r}=0,2729)$. A linhagem Gen Pr 14-2-3 apresenta maior índice $\bar{Z}$ para produtividade de grãos, tempo de cozimento e concentração de potássio, ferro, zinco e cobre nos grãos, sendo indicada para hibridação controlada em programas de melhoramento de feijão para biofortificação.
\end{abstract}

Pavavras-chave: Phaseolus vulgaris L. Variabilidade genética. Correlação de Pearson. Índice $\bar{Z}$.

\footnotetext{
*Autor para correspondência

${ }^{1}$ Recebido para publicação em 23/10/2012; aprovado em 28/06/2013

Pesquisa financiada pelo CNPq e pela CAPES

${ }^{2}$ Departamento de Fitotecnia, Centro de Ciências Rurais, Universidade Federal de Santa Maria/UFSM, Santa Maria-RS, Brasil, nerineia@ hotmail.com ${ }^{3}$ Programa de Pós-Graduação em Agronomia da UFSM, Santa Maria-RS, Brasil, ritimanbrin@ yahoo.com.br

${ }^{4}$ Gerência de Pesquisa e Pós-Graduação, Universidade Tecnológica Federal do Paraná/UTFPR, Pato Branco-PR, Brasil, lindolfostorck@gmail.com ${ }^{5}$ Programa de Pós-Graduação em Bioquímica, Universidade Federal do Pampa/UNIPAMPA, Itaqui-RS, Brasil, marinaprigol@ gmail.com

${ }^{6}$ Departamento de Química, Centro de Ciências Naturais e Exatas, Universidade Federal de Santa Maria/UFSM, Santa Maria-RS, Brasil, cristina.nogueira@pq.cnpq.br
} 


\section{INTRODUCTION}

The greatest volume of the grain from leguminous plants consumed worldwide comes from the common bean, which is the main source of protein in the diet of those living in various countries of Latin America and East and Southern Africa (BROUGHTON et al., 2003). In Latin America, bean consumption represents $8 \%$ to $27 \%$ of the daily nutritional requirement of minerals, sodium, potassium, calcium, phosphorus and magnesium (PENNINGTON; YOUNG, 1990). The common bean is also an important source of iron, zinc and copper (BEEBE; GONZALEZ; RENGIFO, 2000; MESQUITA et al., 2007) which are essential minerals for maintaining physical activity and work capacity, for growth and development and for perfect functioning of the immune system (CUNHA; CUNHA, 1998).

Genetic variability in the concentration of potassium, calcium, iron, zinc and copper in grains has been observed in germplasm of wild and cultivated beans in different countries (AKOND et al., 2011; BEEBE; GONZALEZ; RENGIFO, 2000; BLAIR et al., 2009; BLAIR et al., 2010; GUZMÁNMALDONADO; ACOSTA-GALLEGOS; PAREDESLOPES, 2000; ISLAM et al., 2002, MESQUITA et al., 2007; PEREIRA et al., 2011; PINHEIRO et al., 2010; TALUKDER et al., 2010). This makes it possible to increase of the minerals concentration in bean grains by breeding. In early generations of the common bean, increases have been recorded in grains of $33.6 \%$ in calcium concentration (JOST et al., 2009a), of $94.0 \%$ in iron concentration (JOST et al., 2009b) and of $37.3 \%$ in zinc concentration (ROSA et al., 2010).

To increase the probability of a new bean cultivar being accepted, it is important that not only its nutritional value but also the cooking time be evaluated. This is because beans that become soft enough for consumption after only a few minutes of cooking are preferred by consumers who generally have little time to prepare a meal. In addition, prolonged cooking times are inadvisable because they cause structural changes at the cellular level, resulting in a loss of nutrients (WASSIMI; HOSFIELD; UEBERSAX, 1988).
Since selection is often made based on several characteristics at the same time, it is important to consider the use of selection indices. The $\bar{Z}$ index takes into consideration the sum of variables standardised per lot (MENDES; RAMALHO; ABREU, 2009). Those lines with the largest sums for the $\bar{Z}$ index will be promising for selection, as they will demonstrate superiority in most of the desirable characteristics. A combined selection based on grain yield and both cooking and nutritional quality is new in the bean, and research is still very much in its incipient.

The objectives of this work were to evaluate the genetic variability of the common bean lines as to grain yield, cooking time and mineral concentrations in the grains, to study the linear association between these characteristics and to use the $\bar{Z}$ index for the selection of advanced lines which are superior in most of these characteristics.

\section{MATERIAL AND METHODS}

The experiments were conducted in an area of the Universidade Federal de Santa Maria, in Santa Maria, Rio Grande do Sul (RS), Brazil. Santa Maria is located in the central depression of RS at an altitude of $95 \mathrm{~m}$, at latitude $29^{\circ} 42^{\prime} \mathrm{S}$ and longitude $53^{\circ} 43^{\prime} \mathrm{W}$. The climate in the region is of the Cfa type, temperate rainy, with a rainfall which is well-distributed over the year, being considered subtropical as regards temperature (MORENO, 1961). The field experiments carried out in two growing seasons: normal rainy season (with sowing in October 13, 2010) and dry season (with sowing in February 16, 2011). The two growing seasons differ in their average maximum and minimum air temperatures and monthly rainfall (Table 1).

The experimental design used was of randomized blocks with four replications. Each plot consisted of four rows, with $4.0 \mathrm{~m}$ long and spaced $0.5 \mathrm{~m}$ apart. The two central rows were considered as the useful experimental area $\left(4.0 \mathrm{~m}^{2}\right)$. Treatments consisted of the 14 common bean lines, which ten advanced lines from different breeders: TB 02-24 and TB 02-07 (EMBRAPA Clima Temperado), SM 1107 and SM 1810 (Fundação Estadual

Table 1 - Meteorological data collected in the 8th Meteorology District by the Santa Maria Meteorological Station, located at the Federal University of Santa Maria (latitude $29^{\circ} 42^{\prime}$ S, longitude 53⒋' W, at an altitude of $95 \mathrm{~m}$ ), State of Rio Grande do Sul, Brazil

\begin{tabular}{lcccccccc}
\hline \multirow{2}{*}{ Variable } & \multicolumn{3}{c}{ Normal rainy season 2010 } & \multicolumn{4}{c}{ Dry season 2011 } \\
\cline { 2 - 9 } & Oct & Nov & Dec & Jan & Feb & Mar & Apr & May \\
\hline Maximun temperature $\left({ }^{\circ} \mathrm{C}\right)$ & 24.4 & 27.7 & 30.4 & 32.5 & 30.0 & 28.9 & 26.6 & 21.5 \\
Minimum temperature $\left({ }^{\circ} \mathrm{C}\right)$ & 12.7 & 14.9 & 18.4 & 21.8 & 20.9 & 18.2 & 14.9 & 11.7 \\
Rainfall $(\mathrm{mm})$ & 49.3 & 71.3 & 157.9 & 127.1 & 165.8 & 54.9 & 164.9 & 54.9 \\
\hline
\end{tabular}


de Pesquisa Agropecuária - FEPAGRO), CHC 01175 and CHP 986620 (Empresa de Pesquisa Agropecuária e Extensão Rural de Santa Catarina - EPAGRI), LP 08-90 and LP 07-80 (Instituto Agronômico do Paraná - IAPAR) and BRS MG Realce and CNFP 10104 (EMBRAPA Arroz e Feijão) and four control lines (commercial cultivars): Guapo Brilhante, BRS Valente, Carioca and Pérola. In the dry season of 2011, two more lines were included, Gen P54-3-1 and Gen Pr 14-2-3, from the Instituto Agronômico de Campinas - IAC. All the lines evaluated are from the Middle American gene group, except TB 02-24 and BRS MG Realce, which are from the Andean gene group. As the lines exhibit differences in growth habits $(\mathrm{GH})$, the amount of seeds was calculated to give an expected plant population of 300,000 plants $\mathrm{ha}^{-1}$ for the lines of type I (determinate $\mathrm{GH}$ ), of 250,000 plants $\mathrm{ha}^{-1}$ for the lines of type II (indeterminate $\mathrm{GH}$, with short guides) and of 200,000 plants $\mathrm{ha}^{-1}$ for the lines of type III (indeterminate $\mathrm{GH}$, with long guides) (COMISS ÂO ESTADUAL DE PESQUISA DE FEIJÃO, 2007).

The experimental area has soil classified as a typical alitic Argisol, Hapludalf (EMPRESA BRASILEIRA DE PESQUISA AGROPECUÁRIA, 2006) and presented the following chemical composition in the 2010 growing season: $\mathrm{pH}\left(\mathrm{H}_{2} 0\right)$ : 5.7; organic matter: $20 \mathrm{~g} \mathrm{~kg}^{-1}$; phosphorus: $4.5 \mathrm{mg}$ $\mathrm{dm}^{-3}$; potassium: $112 \mathrm{mg} \mathrm{dm}^{-3}$; calcium: $6.3 \mathrm{cmol}_{\mathrm{c}} \mathrm{dm}^{-3}$; magnesium: $2.8 \mathrm{cmol}_{\mathrm{c}} \mathrm{dm}^{-3}$. The soil was prepared conventionally and fertilization was carried out based on interpretation of the chemical analysis of the soil. At the base, $250 \mathrm{~kg} \mathrm{ha}^{-1}$ of the 5-30-20 formula (nitrogen, phosphorus and potassium) was applied and $20 \mathrm{~kg} \mathrm{ha}^{-1}$ of nitrogen as urea (45\% nitrogen) was added as coverage at the growth stage of the first trifoliolate leaf (V3).

For the growing season of 2011, the experiment was conducted at the same location in the experimental area as that harvested in 2010. Maintenance fertilization and replacement of exported nutrients were therefore carried out as recommended by Comissão de Química e Fertilidade do Solo (2004). At the base, $190 \mathrm{~kg} \mathrm{ha}^{-1}$ of 5-30-20 formula was used and $20 \mathrm{~kg} \mathrm{ha}^{-1}$ of nitrogen (urea) applied as coverage at the time of the first trifoliolate leaf (V3).

The control of insects and weeds was performed whenever necessary in order not to jeopardize the development of the crop. Disease control was not done.

Plants were harvested at maturity and threshing performed manually. Agricultural machinery and equipment were not used to harvest and process the grains to avoid contamination of the samples by heavy metals. After manual removal of impurities and broken grains, the remaining grains were dried in a forcedair drying and sterilization oven $\left(65\right.$ to $\left.70{ }^{\circ} \mathrm{C}\right)$ for approximately 24 hours. Grain moisture was measured with a portable moisture meter and grain yield $\left(\mathrm{kg} \mathrm{ha}^{-1}\right)$ was determined for an average moisture content of $13 \%$.

Evaluation of the cooking time was carried out one month after harvest, using 25 grains per treatment, relating to blocks 1 to 3 . The grains (25) were placed into a $200 \mathrm{ml}$ disposable plastic cup, to which was added $50 \mathrm{ml}$ of distilled water. After eight hours of soaking at room temperature $\left(20^{\circ} \mathrm{C} \pm 2\right)$, the water was removed and the grains were dried lightly with paper towels and placed on the support plate of a Mattson's cooking. The device has 25 pegs, each of $90 \mathrm{~g}$ with a $1.0 \mathrm{~mm}$ tip diameter. Each grain was placed under a peg, and the device was placed into a domestic seven-litre pressure cooker with three litres of boiling distilled water. The pot was kept heated (without a lid) on a medium fire, and as a grain was cooked, a peg pierced the softened grain and fell. The time elapsed from the start of cooking until each peg fell was recorded for the first 13 pegs in order to calculate the average cooking time for each sample (RIBEIRO et al., 2007).

In each growing season, a homogeneous sample of $150 \mathrm{~g}$ of grains per treatment was separated from blocks 1 and 2. From each experimental unit, $10 \mathrm{~g}$ subsamples of grains were oven dried $\left(65\right.$ to $70{ }^{\circ} \mathrm{C}$ ) until reaching an average moisture content of $13 \%$, in a similar manner to that described for the evaluation of seed yield. The subsamples were ground in an analytical micro-mill to obtain particles which were smaller than 1 $\mathrm{mm}$. The minerals were quantified in $0.5 \mathrm{~g}$ of the resulting raw-bean flour which was digested in perchloric acid with concentrated nitric acid $(1 / 5, \mathrm{w} / \mathrm{v})$ at $60{ }^{\circ} \mathrm{C}$ for 12 hours, following the method described by Ribeiro et al. (2012). The concentrations of potassium, calcium, iron, zinc and copper were determined by optical emission spectrometry using inductively coupled plasma (ICPE). The potassium and calcium concentrations were expressed in $\mathrm{g} \mathrm{kg}^{-1}$ of sample dry matter, and those of iron, zinc and copper in $\mathrm{mg} \mathrm{kg}^{-1}$ of sample dry matter.

The data were subjected to variance analysis using the randomized-block model for grain yield (four replications), cooking time (three replications) and minerals concentration (two replications). Bartlett's test (STEEL; TORRIE; DICKEY, 1997) was used to verify the homogeneity of the error variances between the two growing seasons. The $F$ test $(p$ value $<0.05$ ) was used for hypothesis testing of the principle effects, and for the interaction line $\mathrm{x}$ growing season. The effect of the lines was considered as fixed and the remaining (block, season and interaction) as random. Comparison of the averages between lines was carried out 
using the Scott-Knott test ( $\mathrm{p}$ value $=0.05)$. The Pearson linear correlation coefficients were estimated for the seven characteristics using data from blocks 1 and 2 common to all those characteristics, and the significance of the coefficients was verified using Student's t-test ( $\mathrm{p}$-value $=0.05$ ).

Data on grain yield, cooking time, potassium, calcium, iron, zinc and copper were standardised for each plot within each block, making them directly comparable. The selection index ( $\bar{Z}$ index) was estimated as described in Mendes, Ramalho and Abreu (2009). However, as the characteristics had been determined using a different number of replications, the average of the $\bar{Z}$ index was considered for those characteristics present in each block, and then a constant with a value of 3 was added in order to avoid negative values. Graphs were produced to verify the contribution of each standardised characteristic to the value of the $\bar{Z}$ index, allowing visual identification of those lines with the highest averages for the $\bar{Z}$ index for all characteristics, using the same procedure adopted by Mendes, Ramalho and Abreu (2009). Analyses were made with the aid of the Office Excel spreadsheet and Genes software (CRUZ, 2006).

\section{RESULTS AND DISCUSSION}

The experimental error variance for the two growing seasons was homogeneous ( $\mathrm{p}$ value $>0.05$ ), making a joint variance analysis possible for all the evaluated characteristics. The variance analysis showed a significant line $x$ growing season interaction $(p$ value $<0.05)$ in relation to grain yield, cooking time and potassium and iron concentrations in the common bean (Table 2). For these characteristics, the response of common bean lines did not correspond to changes in the environment (at the time of sowing). For the purposes of generalising the behaviour of the lines under different environments, the evaluation of lines in two different seasons at the same site, has a similar significance to the evaluation of lines at two sites in the same season. The important thing is that there be a change in environment. In this case, the environmental change was significant ( $p$-value $<0.05$ ) for grain yield and concentrations of potassium, iron, zinc and copper in the grains. The fact that cooking time was not affected by the environment is pertinent when marketing the product (less information on the package label). Significant line $\mathrm{x}$ environment interaction was also

Table 2 - Degrees of freedom (DF) and mean square (MS) of the joint variance analysis for the data of grain yield (yield, $\mathrm{kg} \mathrm{ha}^{-1}$ ), cooking time (cooking, seconds), minerals concentration in the grain: potassium $\left(\mathrm{g} \mathrm{kg}^{-1}\right.$ of dry matter - DM), calcium (g kg-1 DM), iron ( $\left.\mathrm{mg} \mathrm{kg}^{-1} \mathrm{DM}\right)$, zinc $\left(\mathrm{mg} \mathrm{kg}^{-1} \mathrm{DM}\right)$ and copper $\left(\mathrm{g} \mathrm{kg}^{-1} \mathrm{MS}\right)$ and $\bar{Z}$ index in advanced common bean lines from the normal rainy season 2010 and dry season 2011

\begin{tabular}{|c|c|c|c|c|c|c|}
\hline \multirow{2}{*}{ Source of variation } & \multicolumn{2}{|c|}{ Yield } & \multicolumn{2}{|c|}{ Cooking } & \multicolumn{2}{|c|}{ Potassium } \\
\hline & $\mathrm{DF}$ & MS & $\mathrm{DF}$ & MS & $\mathrm{DF}$ & MS \\
\hline Line (L) & 15 & $709060 *$ & 15 & $57154.9 *$ & 15 & $6.26^{\mathrm{ns}}$ \\
\hline Season $(E)$ & 1 & $39019980 *$ & 1 & $13514.3^{\mathrm{ns}}$ & 1 & $83.67 *$ \\
\hline $\mathrm{LxE}$ & 13 & $271720 *$ & 13 & $36901.3 *$ & 13 & $8.80^{*}$ \\
\hline Block / E & 6 & 060790* & 4 & $27839.6^{*}$ & 2 & $0.61^{\mathrm{ns}}$ \\
\hline Error & 84 & 071470 & 56 & 10784.0 & 28 & 3.68 \\
\hline Mean & & 1959.0 & & 1016.5 & & 11.39 \\
\hline CV\% & & 13.6 & & 10.2 & & 16.8 \\
\hline \multicolumn{7}{|c|}{ Quadrado Médio } \\
\hline & $\mathrm{DF}$ & Calcium & Iron & Zinc & Copper & $\bar{Z}$ index \\
\hline Line (L) & 15 & $0.11^{*}$ & $925.7^{*}$ & $27.3^{\text {ns }}$ & $0.84^{\mathrm{ns}}$ & $1.08^{*}$ \\
\hline Season (E) & 1 & $0.05^{\mathrm{ns}}$ & $3553.7^{*}$ & $120.7 *$ & $5.83^{*}$ & $0.04^{\mathrm{ns}}$ \\
\hline $\mathrm{Lx} \mathrm{E}$ & 13 & $0.09^{\mathrm{ns}}$ & $1336.3^{*}$ & $10.3^{\text {ns }}$ & $0.79^{\mathrm{ns}}$ & $0.34^{\mathrm{ns}}$ \\
\hline Block / E & 2 & $0.01^{\mathrm{ns}}$ & $128.5^{\mathrm{ns}}$ & $6.6^{\mathrm{ns}}$ & $0.43^{\mathrm{ns}}$ & $0.19^{\mathrm{ns}}$ \\
\hline Error & 28 & 0.046 & 312.1 & 20.2 & 0.76 & 0.37 \\
\hline Mean & & 1.55 & 88.78 & 28.65 & 3.68 & 2.99 \\
\hline $\mathrm{CV} \%$ & & 13.8 & 19.9 & 15.7 & 23.7 & 20.3 \\
\hline
\end{tabular}

* Significant by the $\mathrm{F}$ test $(\mathrm{p}$ value $<0.05)$; $\mathrm{ns}=$ not significant; $\mathrm{CV} \%$ : coefficient of variation 
previously observed for grain yield (PERINA et al., 2010; RIBEIRO et al., 2008), for cooking time (RODRIGUES et al., 2005) and for potassium and iron concentrations in the bean grains (MORAGHAN; GRAFTON, 2001). The calcium concentration and the $\bar{Z}$ index were significant only for the lines.

In the normal rainy season 2010, seven lines (CNFP 10104, CHC 01175, LP 08-90, SM 1810, SM 1107, CHP 986620 and LP 07-80) surpassed the commercial cultivars in grain yield (Table 3). In the dry season 2011, nine strains (CNFP 10104, CHC 01175, LP 08-90, SM 1810, SM 1107, LP 07-80, TB 02-07, Gen P5-4-3-1 and Gen Pr14-2-3) had yields similar to those commercial cultivars with the greatest grain yield (Guapo Brilhante and Carioca). In order to register a new common bean cultivar in the National Register of Cultivars - Ministry of Agriculture, Livestock and Supply (NRC/MALS), there is no need to show that the grain yield in advanced lines is higher than that observed in commercial cultivars evaluated in tests for crop value and use (BRASIL, 2006). However, the coefficient of experimental variation of the grain yield should be no more than $25 \%$ for the experiment to meet the standards of experimental accuracy required by the NRC/MALS. In the present study, the coefficients of variation obtained for the grain yield were $12.0 \%$ (2010 normal rainy season) and $15.9 \%$ (2011 dry season), meeting the requirements of the NRC/MALS. Nevertheless, the new line should have at least one characteristic that differentiates it from other commercial cultivars to justify its inclusion in the NRC/MALS. Those characteristics that result in cooking and nutritional quality for the common bean represent marketing advantages for producers, and due to this some, breeding programs have invested in the selection of lines with reduced cooking times and high minerals concentration in the grain.

The cooking time for the grains ranged from 12 min $39 \mathrm{sec}$ (LP 07-80, dry season 2011) to $23 \mathrm{~min} 23$ sec (CNFP 10104, normal rainy season 2010) (Table 3). The Perola and TPS Noble cultivars also presented fast cooking times (from $15 \mathrm{~min} 24 \mathrm{sec}$ to $20 \mathrm{~min} 37 \mathrm{sec}$ ), when they were obtained in five different growing seasons in the Rio Grande do Sul state (RODRIGUES et al., 2005). In the present study, all the common bean lines showed reduced cooking times, and therefore meet the demands

Table 3 - Averages for grain yield $\left(\mathrm{kg} \mathrm{ha}^{-1}\right)$, cooking time (minutes) and concentrations of potassium $\left(\mathrm{g} \mathrm{kg}^{-1} \mathrm{dry} \mathrm{matter} \mathrm{-} \mathrm{DM),}\right.$ calcium $\left(\mathrm{g} \mathrm{kg}^{-1} \mathrm{DM}\right)$ and iron $\left(\mathrm{mg} \mathrm{kg}^{-1} \mathrm{DM}\right)$ in advanced common bean lines, obtained from the normal rainy season 2010 (crop 1) and the dry season 2011 (crop 2)

\begin{tabular}{lrrrrrrrrr}
\hline \multirow{2}{*}{ Line } & \multicolumn{2}{c}{ Yield } & \multicolumn{2}{c}{ Cooking } & \multicolumn{2}{c}{ Potassium } & \multicolumn{2}{c}{ Calcium } & \multicolumn{2}{c}{ Iron } \\
\cline { 2 - 9 } & Crop 1 & Crop 2 & Crop 1 & Crop 2 & Crop 1 & Crop 2 & Mean & Crop 1 & Crop 2 \\
\hline CNFP 10104 & $3102 \mathrm{a} *$ & $1679 \mathrm{a}$ & $23: 23 \mathrm{a}$ & $17: 58 \mathrm{a}$ & $9.1 \mathrm{a}$ & $14.7 \mathrm{a}$ & $1.5 \mathrm{a}$ & $67.3 \mathrm{c}$ & $76.1 \mathrm{~b}$ \\
CHC 01175 & $3066 \mathrm{a}$ & $1466 \mathrm{a}$ & $17: 50 \mathrm{~b}$ & $16: 43 \mathrm{~b}$ & $9.3 \mathrm{a}$ & $14.1 \mathrm{a}$ & $1.6 \mathrm{a}$ & $127.0 \mathrm{~b}$ & $84.6 \mathrm{~b}$ \\
LP 08-90 & $3060 \mathrm{a}$ & $1603 \mathrm{a}$ & $16: 03 \mathrm{~b}$ & $16: 05 \mathrm{~b}$ & $11.7 \mathrm{a}$ & $14.9 \mathrm{a}$ & $1.4 \mathrm{a}$ & $80.9 \mathrm{c}$ & $82.9 \mathrm{~b}$ \\
SM 1810 & $2913 \mathrm{a}$ & $1394 \mathrm{a}$ & $15: 24 \mathrm{~b}$ & $14: 15 \mathrm{~b}$ & $9.1 \mathrm{a}$ & $12.8 \mathrm{a}$ & $1.6 \mathrm{a}$ & $132.5 \mathrm{~b}$ & $64.3 \mathrm{~b}$ \\
SM 1107 & $2798 \mathrm{a}$ & $1762 \mathrm{a}$ & $17: 30 \mathrm{~b}$ & $15: 21 \mathrm{~b}$ & $10.6 \mathrm{a}$ & $15.0 \mathrm{a}$ & $1.7 \mathrm{a}$ & $90.4 \mathrm{c}$ & $76.7 \mathrm{~b}$ \\
CHP 986620 & $2782 \mathrm{a}$ & $1308 \mathrm{~b}$ & $19: 16 \mathrm{~b}$ & $16: 11 \mathrm{~b}$ & $9.1 \mathrm{a}$ & $9.5 \mathrm{~b}$ & $1.3 \mathrm{a}$ & $67.5 \mathrm{c}$ & $78.6 \mathrm{~b}$ \\
LP 07-80 & $2742 \mathrm{a}$ & $1611 \mathrm{a}$ & $14: 00 \mathrm{~b}$ & $12: 39 \mathrm{~b}$ & $9.3 \mathrm{a}$ & $9.3 \mathrm{~b}$ & $1.3 \mathrm{a}$ & $179.5 \mathrm{a}$ & $77.1 \mathrm{~b}$ \\
Guapo Brilhante & $2608 \mathrm{~b}$ & $1445 \mathrm{a}$ & $16: 19 \mathrm{~b}$ & $19: 39 \mathrm{a}$ & $9.5 \mathrm{a}$ & $9.4 \mathrm{~b}$ & $1.6 \mathrm{a}$ & $86.3 \mathrm{c}$ & $78.4 \mathrm{~b}$ \\
TB 02-07 & $2551 \mathrm{~b}$ & $1420 \mathrm{a}$ & $18: 11 \mathrm{~b}$ & $16: 39 \mathrm{~b}$ & $12.5 \mathrm{a}$ & $9.7 \mathrm{~b}$ & $1.7 \mathrm{a}$ & $73.3 \mathrm{c}$ & $103.1 \mathrm{a}$ \\
Carioca & $2438 \mathrm{~b}$ & $1511 \mathrm{a}$ & $15: 42 \mathrm{~b}$ & $15: 58 \mathrm{~b}$ & $9.2 \mathrm{a}$ & $12.4 \mathrm{a}$ & $1.4 \mathrm{a}$ & $98.0 \mathrm{c}$ & $74.2 \mathrm{~b}$ \\
BRS Valente & $2360 \mathrm{c}$ & $1009 \mathrm{~b}$ & $16: 36 \mathrm{~b}$ & $17: 10 \mathrm{~b}$ & $9.4 \mathrm{a}$ & $14.9 \mathrm{a}$ & $1.8 \mathrm{a}$ & $75.1 \mathrm{c}$ & $64.8 \mathrm{~b}$ \\
Pérola & $2158 \mathrm{c}$ & $1096 \mathrm{~b}$ & $16: 52 \mathrm{~b}$ & $17: 43 \mathrm{a}$ & $11.4 \mathrm{a}$ & $12.3 \mathrm{a}$ & $1.7 \mathrm{a}$ & $86.9 \mathrm{c}$ & $72.3 \mathrm{~b}$ \\
BRS MG Realce & $1934 \mathrm{c}$ & $1319 \mathrm{~b}$ & $17: 15 \mathrm{~b}$ & $19: 27 \mathrm{a}$ & $9.0 \mathrm{a}$ & $13.5 \mathrm{a}$ & $1.5 \mathrm{a}$ & $86.7 \mathrm{c}$ & $118.0 \mathrm{a}$ \\
TB 02-24 & $1454 \mathrm{~d}$ & $1174 \mathrm{~b}$ & $15: 56 \mathrm{~b}$ & $20: 26 \mathrm{a}$ & $12.4 \mathrm{a}$ & $9.0 \mathrm{~b}$ & $1.6 \mathrm{a}$ & $106.5 \mathrm{c}$ & $72.4 \mathrm{~b}$ \\
Gen P5-4-3-1 & - & $1442 \mathrm{a}$ & - & $16: 50 \mathrm{~b}$ & - & $13.4 \mathrm{a}$ & $1.9 \mathrm{a}$ & - & $78.5 \mathrm{~b}$ \\
Gen Pr 14-2-3 & - & $1577 \mathrm{a}$ & - & $15: 57 \mathrm{~b}$ & - & $14.8 \mathrm{a}$ & $1.5 \mathrm{a}$ & - & $102.9 \mathrm{a}$ \\
\hline Mean & 2569 & 1426 & $17: 09$ & $16: 45$ & 10.1 & 12.5 & 1.5 & 97.0 & 81.6 \\
CV\%1 & 12.0 & 15.9 & 10.1 & 11.3 & 16.1 & 16.4 & 13.8 & 22.3 & 15.1 \\
\hline Aves
\end{tabular}

${ }^{*}$ Averages not followed by the same letter in any one column, differ between themselves by the Scott-Knott test (p value $=0.05$ ); ${ }^{1} \mathrm{CV}$ : coefficient of variation (percent) 
of consumers, who in terms of activities outside the home and the little time available for cooking, prefer bean grains having quick preparation times.

Potassium concentration ranged from 9.0 (BRS MG Realce) to $12.5 \mathrm{~g} \mathrm{~kg}^{-1}$ of dry matter - DM (TB 02-07) and although there was a significant difference between lines by the F test, application of the Scott-Knott test did not result in stratification between treatments for the same level of significance in the normal rainy season 2010 (Table 3). In the dry season 2011, two groups were formed for potassium concentration in the grains: high potassium (12.3 to $15.0 \mathrm{~g} \mathrm{~kg}^{-1} \mathrm{DM}$ ): CNFP 10104; CHC 01175; LP 08-90; SM 1810; SM 1107; Carioca; BRS Valente; Pérola; BRS MG Realce; Gen P5-4-3-1 and Gen-2 Pr14-2-3, and low potassium (9.0 to $9.7 \mathrm{~g} \mathrm{~kg}^{-1} \mathrm{DM}$ ): CHP 986620; LP 07-80; Guapo Brilhante; TB 02-07 and TB 02-24. The identification of common bean lines having high potassium concentration in the grains is very important in the formulation of diets for people who engage in intense physical activity, and who therefore require higher potassium concentration in their food (LINDINGER, 1995). Whereas lines with low potassium concentration in the grains could be used in diets where potassium is restricted such as prescribed for patients with renal damage (LOUIS; DOLAN, 1970).

The average of the calcium concentration ranged from 1.3 (CHP 986620 and LP 07-80) to $1.9 \mathrm{~g} \mathrm{~kg}^{-1} \mathrm{MS}$ (Gen Pr5-4-3-1), but the application of the Scott-Knott test did not produce stratification between lines at the same level of significance. Similar values for calcium have previously been described in early generations of the common bean (JOST et al., 2009a) and in grains from 29 advanced common bean lines of different tegument colours, grown in Brazil, the United States and Colombia (AKOND et al., 2011).

Iron concentration in the grains showed wide variation between lines for the two growing seasons (Table 3). Values between 67.3 (CNFP 10104) to $179.5 \mathrm{mg} \mathrm{kg}^{-1}$ DM (LP 07$80)$ were recorded in the normal rainy season 2010 , and between 64.3 (SM 1810) to $118.0 \mathrm{mg} \mathrm{kg}^{-1} \mathrm{MS}$ (BRS MG Realce) were observed in the dry season 2011. The iron concentration in the grains of the common bean was affected by the line $\mathrm{x}$ growing season interaction, as observed in the present study and by Araújo et al. (2003). However, all the lines tested showed high iron concentration in the grains for the two growing seasons, following the classification proposed by Tryphone and Nchimbi-Msolla (2010) for grains of the common bean. High iron concentration value in the common bean lines grown in Brazil, were previously described by Jost et al. (2009b) and by Mesquita et al. (2007). Due to this, those lines evaluated in this study can be used in breeding programs for biofortification with iron through controlled hybridization. Additionally, the use of grains from these lines in one or two daily meals needs to be evaluated as an alternative in minimising the problems arising from a lack of iron in the human body.

Grain yield showed a low-magnitude negative correlation with potassium concentration in the common bean $(r=-0.3497)$ (Table 4$)$. As a consequence, the selection of common bean lines with a high grain yield will have only a limited contribution in reducing potassium concentration in the grains.

An estimated low-magnitude positive correlation was found between grain yield and the $\mathrm{zinc}(\mathrm{r}=0.3486)$ and copper concentrations $(r=0.2729)$. Furthermore, the zinc and copper concentrations had a positive correlation $(r=0.3954)$. A positive correlation between zinc and copper was also observed for bean lines grown in Portugal (PINHEIRO et al., 2010). When there is a positive association between two characteristics, an increase in one, results in an increase in the other. In the present study, the magnitude of the association between grain yield and the zinc and copper concentrations was low, thus not favouring indirect selection. In a breeding program therefore it is recommended that the minerals

Table 4 - Estimates of the Pearson correlation coefficients between the characteristics, grain yield (yield), cooking time (cooking) and minerals concentration in the grains: potassium, calcium, iron, zinc and copper, in advanced common bean lines from the normal rainy season 2010 and the dry season 2011

\begin{tabular}{lcccccc}
\hline & Cooking & Potassium & Calcium & Iron & Zinc & Copper \\
\hline Yield & 0.1605 & $-0.3497^{*}$ & 0.1566 & 0.2486 & $0.3486^{*}$ & $0.2729^{*}$ \\
Cooking & & -0.1163 & 0.1071 & $-0.1467^{*}$ & -0.0604 & -0.0033 \\
Potassium & & & 0.0097 & -0.1210 & 0.2121 & 0.0713 \\
Calcium & & & & -0.0008 & 0.2224 & 0.0499 \\
Iron & & & & 0.2026 & 0.1025 \\
Zinc & & & & & $0.3954^{*}$ \\
\hline
\end{tabular}

* Significant by the $\mathrm{t}$-test $(\mathrm{p}$ value $=0.05), \mathrm{n}=60$ observations 
concentration in common bean grains be evaluated in those lines selected for high grain yield, making it possible to select lines with higher nutritional value from among the more productive lines.
The seven lines with the highest averages for the $\bar{Z}$ index for most characteristics are represented graphically in Figure 1. The CNFP 10104 line had the highest average for the $\bar{Z}$ index followed by the SM 1107 , Gen Pr 14-2-3,

Figure 1 - Representation of the $\bar{Z}$ index for grain yield (yield), cooking time (cooking), concentrations of potassium (K), calcium $(\mathrm{Ca})$, iron $(\mathrm{Fe})$, zinc $(\mathrm{Zn})$ and copper $(\mathrm{Cu})$ in grains from the seven lines showing the highest average estimates for the $\bar{Z}$ index
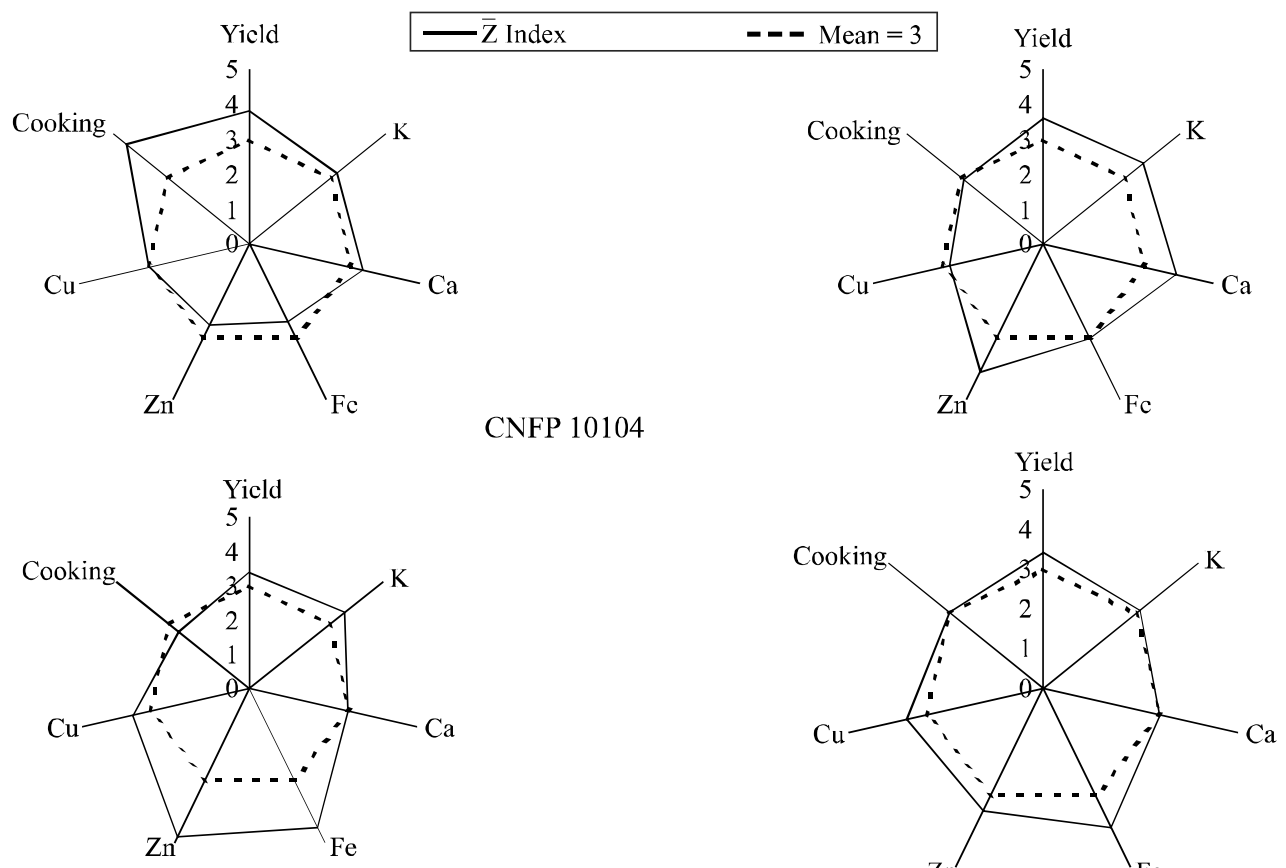

CNFP 10104

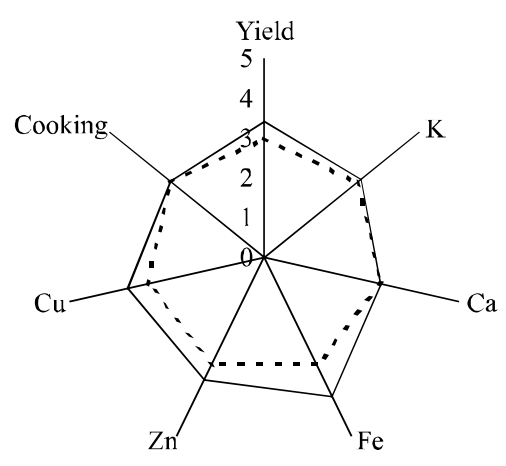

SM 1107

Gen $\operatorname{Pr} 14-2-3$
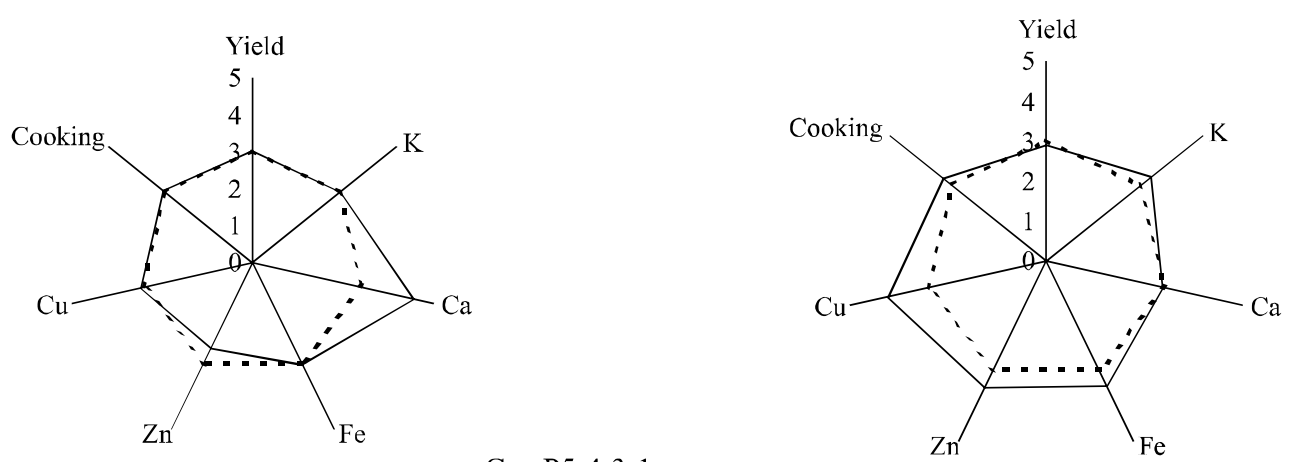

CHC 01175

Gen P5-4-3-1

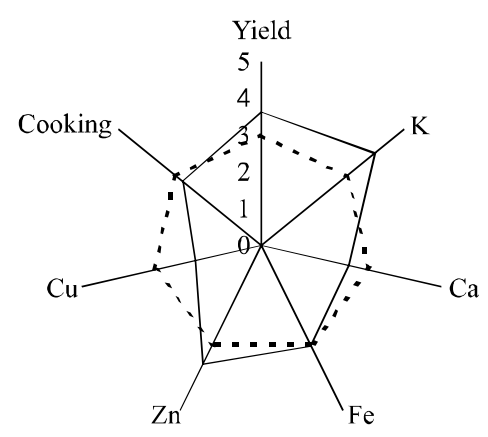

LP 08-90 
CHC 01175, Gen P5-4-3-1, TB 02-07 and LP 08-90 lines. The Gen Pr 14-2-3 line presented higher $\dot{Z}$ indices for grain yield and concentrations of potassium, iron, zinc and copper in the grains, and a lower $\bar{Z}$ index for cooking time. Selection of the Gen Pr 14-2-3 line is therefore recommended, since $\bar{Z}$ indices, favourable for selection, were seen for most of the characteristics.

The Gen Pr 14-2-3 line can be used for crossing with the SM 1107 or Gen P5 -4-3-1 lines, since these showed the highest $\bar{Z}$ index for calcium concentration in the grains. Selection of the obtained recombinants could result in a new cultivar of the common bean, having a higher grain yield, reduced cooking time and high nutritional value.

The development of common bean cultivars, biofortified through breeding, can represent significant advances in the improvement of the nutritional quality of diets, contributing to the reduction of mineral deficiencies that cause health risks, such as those observed in cases of calcium, iron and zinc deficiency in the human body. As beans are the main daily source of protein in many countries (BROUGHTON et al., 2003), biofortification will have a major impact on improving the quality of life for the majority of the population, and therefore needs to be addressed in breeding programs.

\section{CONCLUSIONS}

1. Common bean lines present genetic variability for grain yield, cooking time and calcium and iron concentrations in the grains;

2. Low-magnitude estimates of correlation are obtained between grain yield and potassium $(\mathrm{r}=-0.3497)$, zinc $(\mathrm{r}=0.3486)$ and copper concentrations $(\mathrm{r}=0.2729)$;

3. The Gen $\operatorname{Pr} 14-2-3$ line presents a greater $\bar{Z}$ index for grain yield, cooking time and concentrations of potassium, iron, zinc and copper in the grains, being suitable for controlled hybridization in breeding programs for common bean biofortification.

\section{ACKNOWLEDGEMENTS}

The authors wish to thank the Conselho Nacional de Desenvolvimento Científico e Tecnológico (CNPq) and the Coordenação de Aperfeiçoamento de Pessoal de Nível Superior (CAPES). The authors also wish to thank Mr. Fabiano Kauer (Shimadzu) for his technical support in the ICPE-OES analysis.

\section{REFERENCES}

AKOND, A. S. M. G. M. et al. Minerals (Zn, Fe, Ca and Mg) and antinutrient (phytic acid) constituents in common bean. American Journal of Food Technology, v. 6, n. 3, p. 235-243, 2011.

ARAÚJO, R. et al. Genotype x environment interaction effects on the iron content of common bean grains. Crop Breeding and Applied Biotechnology, v. 3, n. 4, p. 269-274, 2003.

BEEBE, S.; GONZALEZ, V.; RENGIFO, J. Research on trace minerals in the common bean. Food and Nutrition Bulletin, v. 21, n. 4, p. 387-391, 2000.

BLAIR, M. W. et al. Inheritance of seed iron and zinc concentrations in common bean (Phaseolus vulgaris L.). Molecular Breeding, v. 23, n. 2, p. 197-207, 2009.

BLAIR, M. W. et al. Genetic diversity, inter-gene pool introgression and nutritional quality of common beans (Phaseolus vulgaris L.) from Central Africa. Theorical Applied Genetic, v. 121, n. 2, p. 237-248, 2010.

BRASIL. Ministério da Agricultura, Pecuária e Abastecimento. Requisitos mínimos para a determinação do Valor de Cultivo e Uso de feijão (Phaseolus vulgaris), para a inscrição no Registro Nacional de Cultivares - RCN. Brasília: MAPA, 2006. Anexo IV. Disponível em: <http://www.agricultura.gov. br>. Acesso em: 17 jun. 2011.

BROUGHTON, W. J. et al. Beans (Phaseolus spp.): model food legumes. Plant Soil, v. 252, n. 1, p. 55-128, 2003.

COMISSÃO ESTADUAL DE PESQUISA DE FEIJÃO. Indicações técnicas para a cultura do feijão no Rio Grande do Sul. Pelotas: Embrapa Clima Temperado, 2007. 110 p.

COMISSÃODEQUÍMICAEFERTILIDADEDOSOLO. Manual de adubação e de calagem para os estados do Rio Grande do Sul e Santa Catarina. 10. ed. Porto Alegre: Sociedade Brasileira de Ciência do Solo - Núcleo Regional Sul, 2004. 400 p.

CUNHA, D. F.; CUNHA, S. F. C. Microminerais. In: DUTRADE-OLIVEIRA, J. E.; MARCHINI, J. S. Ciências nutricionais. São Paulo: Sarvier, 1998. p. 141-165.

CRUZ, C. D. Programa Genes: estatística experimental e matrizes. Viçosa: Editora UFV, 2006. 285 p.

EMPRESA BRASILEIRA DE PESQUISA AGROPECUÁRIA. Centro Nacional de Pesquisa de Solos. Sistema Brasileiro de Classificação de Solos. 2. ed. Brasília: Embrapa Produção de Informação; Rio de Janeiro: Embrapa Solos, 2006. 306 p.

GUZMÁN-MALDONADO, S. H.; ACOSTA-GALLEGOS, J.; PAREDES-LÓPEZ, O. Protein and mineral content of a novel collection of wild and weedy common bean (Phaseolus vulgaris L.). Journal of the Science of Food and Agriculture, v. 80, n. 13 , p. $1874-1881,2000$.

ISLAM, F. M. A. et al. Seed composition and disease resistance differences among gene pools in cultivated common bean. Genetic Resources and Crop Evolution, v. 49, n. 3, p. 285-293, 2002.

JOST, E. et al. Efeitos gênicos do teor de cálcio em grãos de feijão. Ciência Rural, v. 39, n. 1, p. 31-37, 2009a. 
JOST, E. et al. Potencial de aumento do teor de ferro em grãos de feijão por melhoramento genético. Bragantia, v. 68, n. 1 , p. 35-42, 2009 b.

LINDINGER, M. I. Potassium regulation during exercise and recovery in humans: implications for skeletal and cardiac muscle. Journal of Molecular and Cellular Cardiology, v. 27, n. 4, p. 1011-1022, 1995.

LOUIS, C. J.; DOLAN, E. M. Removal of potassium in potatoes by leaching. Journal of the American Dietetic Association, v. 57, n. 1, p. 42-43, 1970.

MENDES, F. F.; RAMALHO, M. A. P.; ABREU, A. F. B. Índice de seleção para escolha de populações segregantes de feijoeiro-comum. Pesquisa Agropecuária Brasileira, v. 44, n. 10, p. 1312-1318, 2009.

MESQUITA, F. R. et al. Linhagens de feijão (Phaseolus vulgaris L.): composição química e digestibilidade protéica. Ciência e Agrotecnologia, v. 31, n. 4, p. 1114-1121, 2007.

MORAGHAN, J. T.; GRAFTON, K. Genetic diversity and mineral composition of common bean seed. Journal of the Science of Food and Agriculture, v. 81, n. 4, p. 404-408, 2001.

MORENO, J. A. Clima do Rio Grande do Sul. Porto Alegre. Secretaria da Agricultura, 1961. 42 p.

PENNINGTON, J. A. T.; YOUNG, B. Sodium, potassium, calcium, phosphorus and magnesium in foods from the United States total diet study. Journal of Food Composition and Analysis, v. 3, n. 2, p. 145-165, 1990.

PEREIRA, T. et al. Diversidade no teor de nutrientes em grãos de feijão crioulo no Estado de Santa Catarina. Acta Scientiarum Agronomy, v. 33, n. 3, p. 477-485, 2011.

PERINA, E. F. et al. Avaliação da estabilidade e adaptabilidade de genótipos de feijoeiro (Phaseolus vulgaris L.) baseada na análise multivariada da "performance" genotípica. Ciência e Agrotecnologia, v. 34, n. 2, p. 398-406, 2010.
PINHEIRO, C. et al. Diversity of seed mineral composition of Phaseolus vulgaris L. germplasm. Journal of Food Composition and Analysis, v. 23, n. 4, p. 319-325, 2010.

RIBEIRO, N. D. et al. Padronização de metodologia para avaliação do tempo de cozimento dos grãos de feijão. Bragantia, v. 66, n. 2, p. 335-348, 2007.

RIBEIRO, N. D. et al. Adaptação e estabilidade de produção de cultivares e linhagens-elite de feijão no Estado do Rio Grande do Sul. Ciência Rural, v. 38, n. 9, p. 2434-2440, 2008.

RIBEIRO, N. D. et al. Mineral concentrations in the embryo and seed coat of common bean cultivars. Journal of Food Composition and Analysis, v. 26, n. 1/2, p. 89-95, 2012.

RODRIGUES, J. A. et al. Qualidade para o cozimento de grãos de feijão obtidos em diferentes épocas de semeadura. Bragantia, v. 64, n. 3, p. 369-376, 2005.

ROSA, S. S. et al. Potential for increasing the zinc content in common bean using genetic improvement. Euphytica, v. 175, n. 2, p. 207-213, 2010.

STEEL, R. G. D.; TORRIE, J. H.; DICKEY, D. A. Principles and procedures of statistics: a biometrical approach. 3. ed. New York: McGraw Hill Book, 1997. 666 p.

TALUKDER, Z. I. et al. Genetic diversity and selection of genotypes to enhance $\mathrm{Zn}$ and $\mathrm{Fe}$ content in common bean. Canadian Journal of Plant Science, v. 90, n. 1, p. 49-60, 2010.

TRYPHONE, G. M.; NCHIMBI-MSOLLA, S. Diversity of common bean (Phaseolus vulgaris L.) genotypes in iron and zinc contents under screenhouse conditions. African Journal of Agricultural Research, v. 5, n. 8, p. 738-747, 2010.

WASSIMI, N. N.; HOSFIELD, G. L.; UEBERSAX, M. A. Combining ability of tannin content and protein characteristics of raw and cooked dry beans. Crop Science, v. 28, n. 3 , p. $452-458,1988$. 